\title{
Profile of Trace Elements in Selected Medicinal Plants Used for the Treatment of Diabetes in Eritrea
}

\author{
Mussie Sium, ${ }^{1}$ Patrick Kareru, ${ }^{2}$ Joseph Keriko, ${ }^{2}$ Berhane Girmay, ${ }^{3}$ \\ Ghebrehiwet Medhanie, ${ }^{1}$ and Semere Debretsion ${ }^{4}$ \\ ${ }^{1}$ Department of Chemistry, College of Science, Eritrea Institute of Technology, 1056 Maekel, Eritrea \\ ${ }^{2}$ Department of Chemistry, Jomo Kenyatta University of Agriculture and Technology (JKUAT), Nairobi 62000-00200, Kenya \\ ${ }^{3}$ Department of Chemistry, School of Pharmacy, College of Health Sciences, 8566 Asmara, Eritrea \\ ${ }^{4}$ SGS, Mineral Assay Laboratory, Bisha Mining Share Company, 4275 Asmara, Eritrea \\ Correspondence should be addressed to Mussie Sium; mussies2013@gmail.com
}

Received 29 June 2016; Revised 12 September 2016; Accepted 15 September 2016

Academic Editor: Kazuyuki Tobe

Copyright (C) 2016 Mussie Sium et al. This is an open access article distributed under the Creative Commons Attribution License, which permits unrestricted use, distribution, and reproduction in any medium, provided the original work is properly cited.

\begin{abstract}
This study was designed to investigate the profile of certain trace elements having therapeutic properties related to diabetes mellitus. The investigated plants were Aloe camperi, Meriandra dianthera, Lepidium sativum, Brassica nigra, and Nigella sativa. These plants are traditionally used in the management of diabetes in Eritrea. The elemental analysis was conducted using inductively coupled plasma optical emission spectrometry (ICP-OES) and flame atomic absorption spectroscopy (FAAS) techniques. The accuracy of the methods was verified using in-house reference materials (CRMs) and no significant differences were observed between the measured and certified values. The analysis displayed variable concentrations of the different trace elements including $\mathrm{Zn}, \mathrm{Cr}, \mathrm{V}$, $\mathrm{Mn}$, and Se in the plants. Moreover, the levels of major elements, such as $\mathrm{Mg}, \mathrm{Ca}, \mathrm{K}, \mathrm{Na}$, and $\mathrm{Ba}$, and heavy metals, such as Fe, $\mathrm{Cu}, \mathrm{Ni}, \mathrm{Co}, \mathrm{As}$, and $\mathrm{Pb}$, were determined and found to be in the permissible limit defined by WHO. Among the plants, Meriandra dianthera showed the highest levels of $\mathrm{Mn}, \mathrm{Cr}$, V, and other elements and the values were significantly different $(P<0.05)$.
\end{abstract}

\section{Introduction}

Trace elements have been identified for a long time as potential candidates for improving metabolic disorders including diabetes [1]. It is widely believed that some trace elements, such as $\mathrm{Zn}, \mathrm{Cr}, \mathrm{V}, \mathrm{Mg}, \mathrm{Mn}$, and Se serve as cofactors of antioxidative enzymes and play an important role in protecting the insulin secreting pancreatic $\beta$-cells, which are sensitive to free radical damage $[2,3]$. It has also been reported that the imbalance of some essential trace elements might adversely affect pancreatic islet and cause development of diabetes [4] and thus some trace elements have been recommended as dietary supplement to alleviate the impaired insulin metabolism in diabetic patients $[5,6]$. Some researchers have also shown that trace elements beneficially affect the complications of diabetes mellitus [7]. Clinical studies suggest that the body's balance of mineral trace elements is disrupted by diabetes and thus diabetic individuals are susceptible to trace element deficiency [8]. Even though trace elements are important for the normal functioning of the body, they can be harmful and toxic at high concentrations [9]. Therefore profiling the levels of these elements is mandatory in monitoring the safety of herbal preparations employed in the management of diabetes and other ailments.

The most widely and commonly used techniques of elemental analysis, providing acceptable levels of precision and accuracy, include flame atomic absorption spectrometry (FAAS), graphite furnace atomic absorption spectrometry (GFAAS), inductively coupled plasma atomic emission spectrometry (ICP-AES), and inductively coupled plasma mass spectrometry (ICP-MS) [10]. The present work focuses on analysis of the levels of trace elements and their therapeutic role in the management of diabetes from selected Eritrean medicinal plants. The investigated plants were Aloe camperi, Meriandra dianthera, Lepidium sativum, Brassica nigra, and Nigella sativa. These plants have been traditionally used for the treatment of diabetes and other ailments in Eritrea [11]. The profile of trace and other elements in Aloe camperi and 
Meriandra dianthera is reported for the first time in this paper.

\section{Materials and Methods}

2.1. Sampling. Aloe camperi and Meriandra dianthera are wild plants and their leaves were collected from Adi-Hawisha $\left(15^{\circ} 14^{\prime} 34^{\prime \prime}\right.$ North $38^{\circ} 58^{\prime} 14^{\prime \prime}$ East), Central Zone, Eritrea. Moreover, dry seeds of Lepidium sativum, Brassica nigra, and Nigella sativa were purchased from a local market in Asmara, Eritrea. The plants were washed using distilled water, dried in shade, and then heated on a heating block in an oven for complete dryness. They were finely powdered using an electric blender and fed through a sieve $(0.50 \mathrm{~mm})$ and saved until further use.

2.2. Chemicals and Reagents. Analytical grade chemicals and reagents were purchased from Sigma-Aldrich Company. 65\% nitric acid $\left(\mathrm{HNO}_{3}\right), 30 \%$ hydrogen peroxide $\left(\mathrm{H}_{2} \mathrm{O}_{2}\right), 32 \%$ Hydro chloric acid $(\mathrm{HCl})$, and $98 \%$ sulphuric acid $\left(\mathrm{H}_{2} \mathrm{SO}_{4}\right)$ were used for digestion purposes. Ultrapure-deionized water $(18 \Omega)$ was used throughout the study. The glassware was soaked in $3 \mathrm{M} \mathrm{HNO}_{3}$ for the whole night and washed and rinsed with deionized water to minimize the chances of interferences. All the chemical analyses were conducted under extractor hood and a digital IR Vortex Mixer (S/N296058 made in Italy) was used for mixing of the solutions.

2.3. Standards and Calibration. Different custom-grade multielement standard solutions of PerkinElmer Pure were employed for the calibration and in-house certified reference materials (CRMs) for biological materials, developed using the "ISO Guide 80," were used for comparison purposes [14]. Calibration curves for each element were constructed in triplicate using six different concentrations, giving regression coefficient $\left(r^{2}\right)$ values which ranged from 0.9957 to 0.9996 . An internal-standard stock solution of $100 \mathrm{mg} / \mathrm{L}$ Lutetium (Lu) was prepared from single-element stock solutions.

2.4. Sample Digestion and Preparation. Each sample (0.5 g) was weighed accurately using a 4-decimal-place analytical balance and placed in a digestive tube. The samples were initially digested with concentrated $\mathrm{HNO}_{3}(5 \mathrm{~mL})$ at $175^{\circ} \mathrm{C}$ for $40 \mathrm{~min}$ and then at $150^{\circ} \mathrm{C}$ for $90 \mathrm{~min}$. After the mixture was cooled, $1 \mathrm{~mL} \mathrm{HNO}_{3}$ and $0.5 \mathrm{~mL} \mathrm{H}_{2} \mathrm{SO}_{4}$ were added and the mixture was heated at $175^{\circ} \mathrm{C}$ for $60 \mathrm{~min}$. The mixture was allowed to cool and $\mathrm{H}_{2} \mathrm{O}_{2}(2 \mathrm{~mL})$ was added dropwise and heated at $140^{\circ} \mathrm{C}$ for $10 \mathrm{~min}$ to remove any remaining $\mathrm{NO}_{2}$ that might interfere in the measurement. The resulting mixture was transferred to a calibrated flask and $\mathrm{HCl}(8 \mathrm{~mL})$ was added and the entire filtrate was diluted suitably with ultrapure deionized water to $25 \mathrm{~mL}$. Samples were immediately analysed following the digestion.

2.5. Instrumental Analysis. A dual viewing ICP-OES (Perkin Elmer Optima 8300, made in Singapore) coupled to an ultrasonic nebulizer CETAC 6000AT+ (CETAC, Omaha, NE, USA) was employed for the analysis of the trace and other elements. The Windows 7 compatible S/W provided by Perkin Elmer was used to process the spectral data
TABLE 1: The operating conditions of the ICP-OES.

\begin{tabular}{lc}
\hline Condition & Setting \\
\hline Power & $1.3 \mathrm{~kW}$ \\
Plasma gas glow & $15 \mathrm{~L} / \mathrm{min}$ \\
Auxiliary gas flow & $1.5 \mathrm{~L} / \mathrm{min}$ \\
Spray chamber type & Glass cyclonic (single-pass) \\
Torch & Standard one-piece quartz axial \\
Nebulizer type & Sea spray \\
Nebulizer flow & $0.7 \mathrm{~L} / \mathrm{min}$ \\
Pump speed & $2-4 \mathrm{rpm}$ \\
Total sample usage & $2 \mathrm{~mL}$ \\
Replicate read time & $5 \mathrm{~s}$ \\
Number of replicates & 2 \\
Sample undertake delay time & $15 \mathrm{~s}$ \\
Stabilization time & $40 \mathrm{~s}$ \\
Rinse time & $20 \mathrm{~s}$ \\
Fast pump & Off \\
Background correction & Fitted \\
\hline
\end{tabular}

for calculating sample concentrations by comparing light intensities measured at various wavelengths for standard solutions with intensities from the sample solutions. The operating conditions set for the ICP-OES are shown in Table 1. Moreover, the levels of $\mathrm{Cu}, \mathrm{Pb}, \mathrm{Zn}$, and Fe were studied using FAAS (Agilent 240FS, made in Australia). The dilute filtrate solutions of the digested plant samples were transferred into test tubes and about $20 \mathrm{~mL}$ of the resulting solution was then fed in to the air-acetylene FAAS. Suitable hollow cathode lamps were used to measure the absorbance of the elements at their resonance wavelengths. The optimized operating conditions for the FAAS are shown in Table 2.

2.6. Statistical Analysis. Data for the concentrations of trace and other elements were processed to obtain mean and standard error of mean (SEM). One-way analysis of variance followed by Student's $t$-test was used to compare the mean values. A value of $P<0.05$ was considered to be statistically significant.

\section{Results and Discussion}

Before the analysis of the elements, the accuracy of the methods was verified using in-house certified reference materials (CRMs) digested using dry ashing. As exhibited in Figure 1, the calculated relative errors were as follows: Mg: 0.36, Ba: 0.58, Ca: 1.56, K: 0.26, Na: 1.11, Al: 0.17, Sr: 0.61, Zn: 0.44, Cr: -1.65 , V: 1.89, Mn: -0.27 , Se: 0.06, Fe: 0.28, Cu: 0.28, Li: 1.96, and Co: 7.69. Except for $\mathrm{Cr}$ and $\mathrm{Mn}$, all the elements demonstrated positive relative errors and the deviations from the mean values were small. There was no significant difference in the measured and certified values. Therefore, the calculated relative errors revealed high accuracy of the method, suggesting that this method can be used for routine analyses of trace and heavy metals in herbal products. The concentrations of the elements analysed using 
TABLE 2: The operating conditions of the FAAS.

\begin{tabular}{|c|c|c|c|c|}
\hline \multirow{2}{*}{ Parameter } & \multicolumn{4}{|c|}{ Element matrix } \\
\hline & $\mathrm{Cu}$ & $\mathrm{Pb}$ & $\mathrm{Zn}$ & $\mathrm{Fe}$ \\
\hline Wavelength & $324.8 \mathrm{~nm}$ & $283.3 \mathrm{~nm}$ & $213.9 \mathrm{~nm}$ & $372.0 \mathrm{~nm}$ \\
\hline Slit width & $0.5 \mathrm{~nm}$ & $0.5 \mathrm{~nm}$ & $0.5 \mathrm{~nm}$ & $0.2 \mathrm{~nm}$ \\
\hline Gain & $60 \%$ & $29 \%$ & $33 \%$ & $55 \%$ \\
\hline Lamp current & $4.0 \mathrm{~mA}$ & $10.0 \mathrm{~mA}$ & $5.0 \mathrm{~mA}$ & $5.0 \mathrm{~mA}$ \\
\hline Flame type & Air/acetylene & Air/acetylene & Air/acetylene & Air/acetylene \\
\hline Air flow & $13.50 \mathrm{~L} / \mathrm{min}$ & $13.50 \mathrm{~L} / \mathrm{min}$ & $13.50 \mathrm{~L} / \mathrm{min}$ & $14.90 \mathrm{~L} / \mathrm{min}$ \\
\hline Acetylene flow & $2.20 \mathrm{~L} / \mathrm{min}$ & $2.20 \mathrm{~L} / \mathrm{min}$ & $2.50 \mathrm{~L} / \mathrm{min}$ & $2.20 \mathrm{~L} / \mathrm{min}$ \\
\hline
\end{tabular}

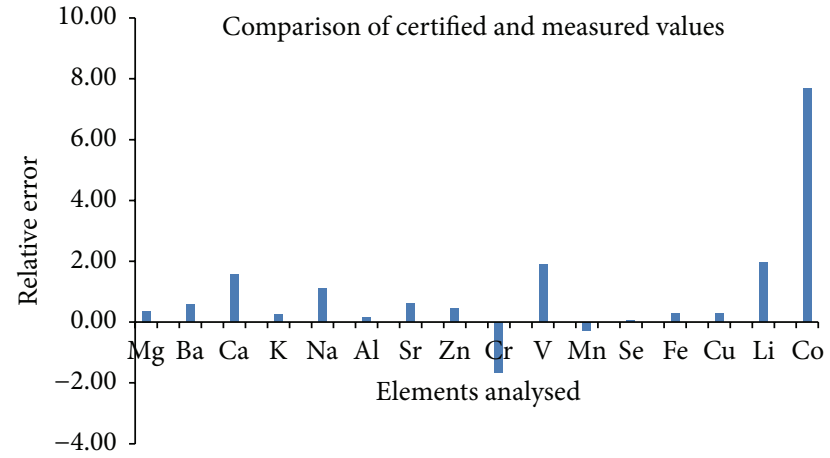

FIGURE 1: The relative error based on comparison of the certified and measured values.

the ICP-OES and FAAS are furnished in Tables 3(a) and 3(b). A total of 16 elements were analysed and special emphasis was given to the levels of $\mathrm{Zn}, \mathrm{Cr}$, Se, Mg, Mn, V, and Mg. Summary of the results and related discussions of the trace elements and magnesium are briefly described below.

3.1. Zinc ( $\mathrm{Zn})$. In this study, a substantial quantity of $\mathrm{Zn}$ was determined in all the plants. Maximum amount (in ppm, dry weight) of $\mathrm{Zn}$ was found in the seed samples of Nigella sativa (52.23), followed by Brassica nigra (37.90), and the lowest in Aloe camperi (23.25). Based on Tukey's multiple comparisons test, there was significant difference $(P<0.01)$ in the levels of $\mathrm{Zn}$ among the plants. Zn plays a crucial role in the storage and secretion of insulin, which subsequently increases the uptake of glucose [15]. The role of $\mathrm{Zn}$ in the production of insulin and catalysis of numerous enzymatic reactions has been reported [16]. The low level of $\mathrm{Zn}$ in plasma adversely affects the ability of islet cells to produce and secrete insulin [17]. Moreover, it may aggravate the insulin resistance in type 2 diabetes and thus causes other complications [18].

3.2. Chromium (Cr). Cr was found in the range of 1.18 to $1.86 \mathrm{ppm}$, where the highest concentration was detected in Meriandra dianthera, while the lowest value was in Nigella sativa. There was no significant difference in the levels of $\mathrm{Cr}$ among the plants. Cr is a crucial trace element with many sites of action and has a vital biological activity which is necessary in glucose homeostasis [19]. It regulates insulin and blood glucose levels by stimulating insulin signalling pathway and metabolism and thus it may improve insulin sensitivity.
Modulation of lipid metabolism by $\mathrm{Cr}$ in peripheral tissues may represent an additional novel mechanism of action [20]. Deficiency of $\mathrm{Cr}$ or its biological active form has been implicated in the pathogenesis of insulin resistance and diabetes [8].

3.3. Vanadium (V). The concentration (in $\mathrm{ppm}$ ) of $\mathrm{V}$ in the medicinal plants ranged from 1.05 in Lepidium sativum to 9.38 in Meriandra dianthera. The levels of $\mathrm{V}$ were significantly different $(P<0.01)$ among the plants. Vanadium has been known for long to possess antidiabetic properties [21]. It affects various aspects of carbohydrate metabolism including glucose transport, glycolysis, and glucose oxidation and glycogen synthesis [22]. Vanadium acts primarily as an insulin mimetic agent, although enhanced insulin activity and increased insulin sensitivity have also been noted [23]. Besides, it stimulates glucose uptake without affecting endogenous levels [24]. In vivo studies show the beneficial effects of various vanadium salts in mild or severe diabetes [22].

3.4. Manganese $(\mathrm{Mn})$. Based on the results portrayed in Table 3(b), the lowest concentration of Mn was observed in Lepidium sativum and amounted to $18.51 \mathrm{ppm}$, while the highest level (82.03 ppm) was in Meriandra dianthera. The level of Mn, among the plants, was significantly different $(P<$ $0.001)$. It has been reported that $\mathrm{Mn}$ is involved in normal immune functions, regulation of blood sugar and cellular energy, and the defence mechanisms against free radicals [25]. Mn activates certain enzymes that play important roles in the metabolism of carbohydrates, amino acids, and cholesterol. $\mathrm{Mn}$ is also required for normal insulin synthesis, its secretion, and an alteration in its metabolism has been implicated in diabetes development [26]. Mn deficiency can result in impaired glucose tolerance, altered carbohydrate and lipid metabolism, impaired insulin secretion, and skeletal abnormalities [27].

3.5. Selenium (Se). Investigation of the level of Se revealed that the element exists in a very low concentration in all the plants. The range of Se was 25.47 up to $72.64 \mathrm{ppb}$ whereby the highest level of the element was observed in Nigella sativa. The values of Se were not statistically different among the investigated plants. Due to its antioxidant properties, Se might be able to prevent the development of diabetes 


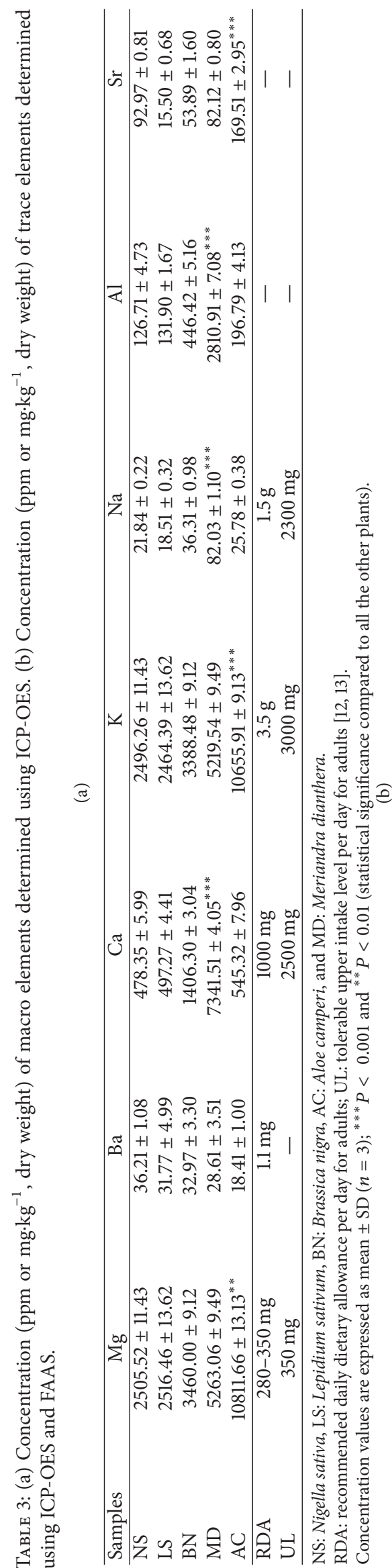



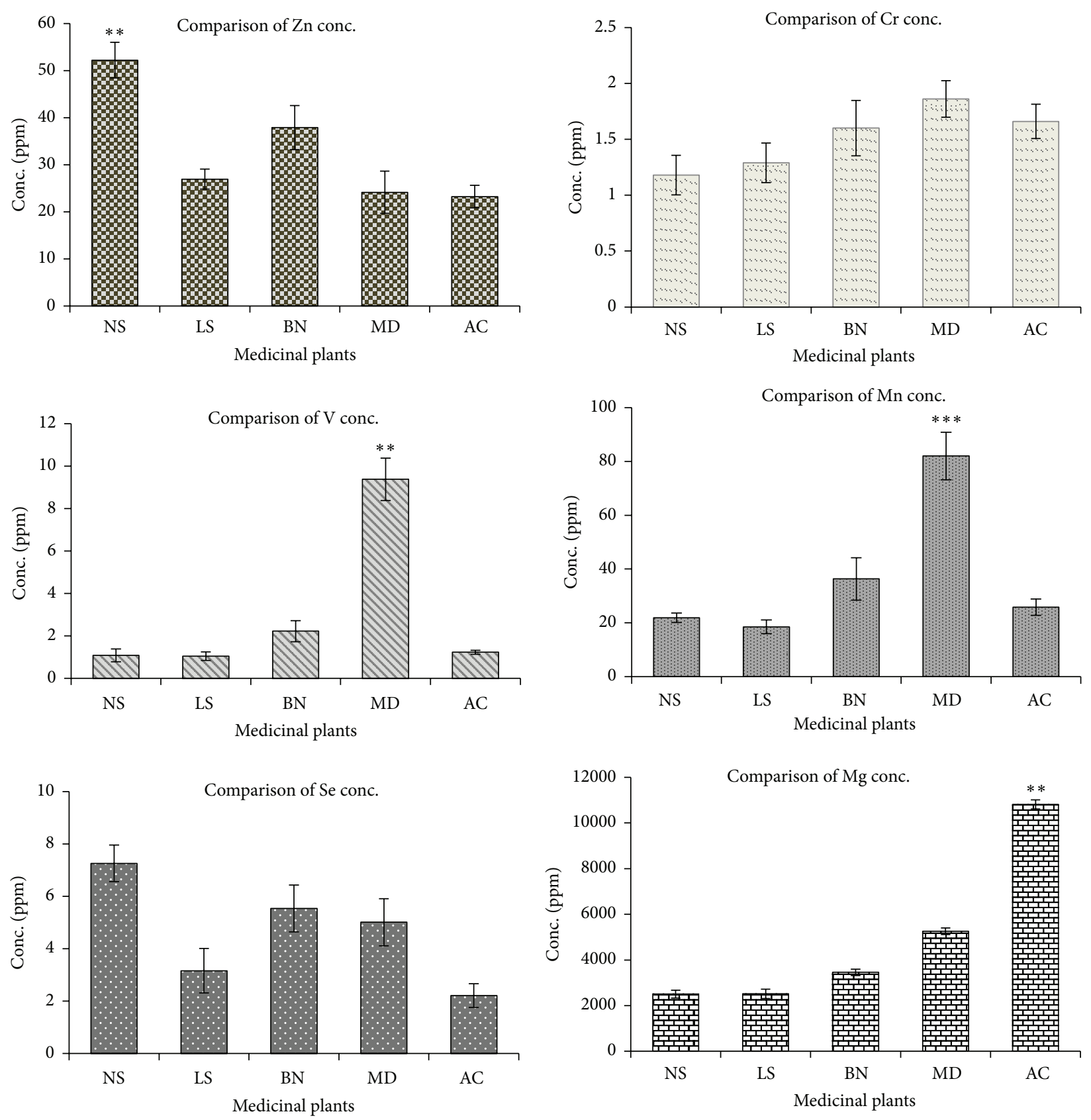

Figure 2: Comparison of the levels of $\mathrm{Zn}, \mathrm{Cr}, \mathrm{V}, \mathrm{Mg}, \mathrm{Mn}$, and Se among the plants. ${ }^{* * *} P<0.001$ and ${ }^{* *} P<0.01$ represent statistical significance of the level of the element in one plant relative to the others.

and associated complications [23]. In addition, selenate, an inorganic form of Se, mimics insulin activity in experimental models [28]. It has been reported that Se could also affect carbohydrate metabolism and the blood glucose-lowering action of oral selenate has been demonstrated in chronically treated diabetic rats [29].

3.6. Magnesium $(\mathrm{Mg})$. The level of $\mathrm{Mg}$ was detected in substantial quantity in all the plants. It ranged from $10.8 \mathrm{ppm}$ in Aloe camperi to $25.05 \mathrm{ppm}$ in Nigella sativa. The level of $\mathrm{Mg}$ was relatively variable and thus was statistically different $(P<$ $0.01) . \mathrm{Mg}$ is a cofactor of various enzymes in carbohydrate oxidation and plays an important role in glucose transporting mechanism of the cell membrane. It is also involved in insulin secretion, binding, and activity [30]. It has a vital role in the phosphorylation reactions of glucose and its metabolism and it may influence the release and activity of the hormones that help control blood glucose levels [31]. It was demonstrated that $\mathrm{Mg}$ deficiency might lead to a decrease in insulin mediated glucose uptake and has been associated with the development of insulin resistance [32].

As presented in Figure 2, Meriandra dianthera showed higher levels (in ppm) of the trace elements including Mn, V, 
and $\operatorname{Cr}(82.03,9.38$, and 1.86, resp.). The plant also exhibited the highest levels (in ppm) of Fe (1241.05) and Co (1.48) as compared to the other plants. Iron is an important trace element and iron protein mixtures play vital role in the metabolism of all living organisms [33] and cobalt has been demonstrated to boost the effects of insulin and its action and the efficiency of cobalt as an antidiabetic agent has been proven [34]. As recently published, the in vivo antidiabetic activity of Meriandra dianthera elicited the highest glucoselowering effect [35] compared to the other plants and thus the reported bioactivity of the plant may be partly attributed to the presence of some of the trace elements that are involved in insulin production and action.

Furthermore, Meriandra dianthera offered the highest level of the major elements including $\mathrm{Ca}, \mathrm{Al}$, and Li. Special mention should be made of $\mathrm{Ca}$ and $\mathrm{Al}$, which have anomalous values (in ppm) of 7341.51 and 2810.91, respectively. These values are extremely higher compared to the values measured in the other plants $(P<0.001)$. Similarly, as shown in Table 3(a), Aloe camperi displayed the highest levels (in ppm) of $\mathrm{Mg}, \mathrm{K}$, and $\mathrm{Sr}(10811,10646$, and 169, resp.) compared to the other plants $(P<0.01)$. However, the plant showed lowest levels of $\mathrm{Zn}, \mathrm{V}$, and Se compared to the other plants (Figure 1). There are no reported levels of trace and major elements related to Meriandra dianthera and Aloe camperi.

The results found in the present work were compared with the values previously reported and thus analysis of Nigella sativa seeds from Turkey showed that they have 0.12 , $117.32,41.42,30.26,28.56$, and 2.55 ppm of $\mathrm{Co}, \mathrm{Fe}, \mathrm{Zn}, \mathrm{Cu}$, $\mathrm{Mn}$, and $\mathrm{Cr}$, respectively [36]. Apart from the levels of $\mathrm{Fe}$ and Co, all the values found in this study were similar to the levels of the elements reported from Turkey. Moreover, Shomar [37] reported the levels of $\mathrm{Cr}, \mathrm{Cu}, \mathrm{Fe}, \mathrm{Mn}, \mathrm{Al}, \mathrm{Ba}$, $\mathrm{Mg}$, and $\mathrm{K}$ in Nigella sativa from Egypt as 4.2, 14.5, 114, 47.4, 99.2, 14.0, 2356, and 9900 ppm, respectively. Current results presented elevated levels of $\mathrm{Cu}, \mathrm{Fe}$, and $\mathrm{Al}$ compared to the values reported from Egypt. On contrary, the levels of $\mathrm{Mn}, \mathrm{Cr}, \mathrm{Ba}$, and $\mathrm{K}$ reported from Egypt were higher than the values determined in this paper. Similarly, analysis of the levels (in ppm, dry weight) of Brassica nigra seeds from India using AAS [38] gave lower levels of $\mathrm{Cu}$ (5.50) and $\mathrm{Fe}$ (184.0) compared to the current report of the elements $(32.97$ and 847.64, resp.). However, the levels of $\mathrm{Zn}$ and $\mathrm{Mn}$ were very similar in both reports. Plants have the ability to uptake metals as nutrient from the soil and its environment which are so essential for their physiological and biochemical growth and thus the difference in the levels of the trace elements from different countries could be due to the variation in soil types, agricultural and industrial activities, and local growing conditions such as differences in water, plant interactions, and weather $[39,40]$.

The highest levels of $\mathrm{Cu}$ and Se were observed in the seeds of Nigella sativa (36.21 ppm and $72.64 \mathrm{ppb}$, resp.). Low concentrations of Co (0.19-1.48 ppm) and Li (0.18$0.86 \mathrm{ppm}$ ) were observed in all the plant samples. Besides, the concentrations of metals such as lead $(\mathrm{Pb})$, cadmium $(\mathrm{Cd})$, and arsenic (As) present in the leaves and seeds of the plants were not quantifiable. It is known that excess concentration of these elements is toxic and thus can disrupt the glucose uptake and alter the related molecular mechanism in glucose regulation [41]. Based on literature review $[12,13]$, Tables 3(a) and 3(b) summarized the recommended dietary allowance (RDA) and tolerable upper levels (UL) of most of the elements and thus it can be deduced that the existing profile of the trace and other elements, based on WHO 2008 and WHO 2011 reports $[42,43]$, was within the permissible limits.

\section{Conclusion}

Overall, the results indicated the presence of characteristic level of trace elements including $\mathrm{Zn}, \mathrm{Cr}, \mathrm{V}, \mathrm{Mn}, \mathrm{Se}$, and $\mathrm{Mg}$ that are associated with the glucose-lowering effects. The levels of the trace elements were within the permissible limit set by the FAO/WHO. Even though the relationship between diabetes and trace elements is complex and is most probably related to a combination of multiple interacting effects, the results obtained can be supplementary to the reported bioactivities of the medicinal plants.

\section{Competing Interests}

No potential competing interests relevant to this paper were reported.

\section{Acknowledgments}

The authors would like to greatly acknowledge Bisha Mining Share Company for their support in the analysis of the elements using the ICP-OES and FAAS available in the company.

\section{References}

[1] S. Gaur and R. Agnihotri, "Trace mineral micronutrients and chronic periodontitis-a review," Biological Trace Element Research, vol. 173, no. 397, pp. 1-14, 2016.

[2] M. P. Ngugi, M. J. Njagi, M. C. Kibiti et al., "Trace elements content of selected Kenyan anti-diabetc medicinal plants research," International Journal of Current Pharmaceutical Research, vol. 4, no. 3, pp. 39-42, 2012.

[3] D. J. Candilish, "Minerals," Journal of the American College of Nutrition, vol. 17, pp. 286-310, 2000.

[4] A. R. Khan and F. R. Awan, "Metals in the pathogenesis of type 2 diabetes," Journal of Diabetes and Metabolic Disorders, vol. 13, article 16, 2014.

[5] T. A. Clark, J. F. Deniset, C. E. Heyliger, and G. N. Pierce, "Alternative therapies for diabetes and its cardiac complications: role of vanadium," Heart Failure Reviews, vol. 19, no. 1, pp. 123-132, 2014.

[6] B. Li, Y. Tan, W. Sun et al., "The role of zinc in the prevention of diabetic cardiomyopathy and nephropathy," Toxicologyl Mechanism Methods, vol. 23, pp. 27-33, 2013.

[7] D. Purnima and L. K. Kazi, "Quantitative estimation of some essential minerals of gymnema sylvestre: a potential herb in counteracting complications of diabetes," International Journal of Research Studies in Biosciences, vol. 3, no. 1, pp. 71-74, 2015.

[8] R. Niamat, M. A. Khan, K. Y. Khan et al., "Element content of some ethnomedicinal Ziziphus Linn. species using atomic absorption spectroscopy technique," Journal of Applied Pharmaceutical Science, vol. 2, no. 3, pp. 96-100, 2012. 
[9] A. Chrzan, "Monitoring bioconcentration of potentially toxic trace elements in soils trophic chains," Environmental Earth Sciences, vol. 75, no. 160, p. 786, 2016.

[10] B. J. Bolann, R. Rahil-Khazen, H. Henriksen, R. Isrenn, and R. J. Ulvik, "Evaluation of methods for trace-element determination with emphasis on their usability in the clinical routine laboratory," Scandinavian Journal of Clinical and Laboratory Investigation, vol. 67, no. 4, pp. 353-366, 2007.

[11] M. Demoz, K. Gachoki, K. Mungai, and B. Negusse, "Ethnobotanical survey and preliminary phytochemical studies of plants traditionally used for diabetes in eritrea," European Journal of Medicinal Plants, vol. 9, no. 2, pp. 1-11, 2015.

[12] R. A. M. Dhonukshe-Rutten, J. Bouwman, K. A. Brown et al., "EURRECA-evidence-based methodology for deriving micronutrient recommendations," Critical Reviews in Food Science and Nutrition, vol. 53, no. 10, pp. 999-1040, 2013.

[13] EFSA, Tolerable Upper Intake Levels for Vitamins and MineralsScientific Committee on Food/Scientific Panel on Dietetic Products, Nutrition, Allergies, EFSA, Brussels, Belgium, 2006.

[14] ISO Guide 80, "Guidance for the in-house preparation of quality control materials (QCMs)," 2014.

[15] Y. V. Li, "Zinc and insulin in pancreatic beta-cells," Endocrine, vol. 45, no. 2, pp. 178-189, 2014.

[16] W. Maret, "Zinc biochemistry: from a single zinc enzyme to a key element of life," Advances in Nutrition, vol. 4, no. 1, pp. 8291, 2013.

[17] J. R. Brender, K. Hartman, R. P. R. Nanga et al., "Role of zinc in human islet amyloid polypeptide aggregation," Journal of the American Chemical Society, vol. 132, no. 26, pp. 8973-8983, 2010.

[18] M. Hashemipour, R. Kelishadi, J. Shapouri et al., "Effect of zinc supplementation on insulin resistance and components of the metabolic syndrome in prepubertal obese children," Hormones, vol. 8, no. 4, pp. 279-285, 2009.

[19] M. M. Guimarães, A. C. Carvalho, and M. S. Silva, "effect of chromium supplementation on the glucose homeostasis and anthropometry of type 2 diabetic patients: double blind, randomized clinical trial," Journal of Trace Elements in Medicine and Biology, vol. 36, pp. 65-72, 2016.

[20] W. Qiao, Z. Peng, Z. Wang, J. Wei, and A. Zhou, "Chromium improves glucose uptake and metabolism through upregulating the mRNA levels of IR, GLUT4, GS, and UCP3 in skeletal muscle cells," Biological Trace Element Research, vol. 131, no. 2, pp. 133-142, 2009.

[21] W. T. Cefalu, J. Rood, P. Pinsonat et al., "Characterization of the metabolic and physiologic response to chromium supplementation in subjects with type 2 diabetes mellitus," Metabolism: Clinical and Experimental, vol. 59, no. 5, pp. 755-762, 2010.

[22] K. H. Thompson and C. Orvig, "Vanadium in diabetes: 100 years from phase 0 to phase i," Journal of Inorganic Biochemistry, vol. 100, no. 12, pp. 1925-1935, 2006.

[23] N. Wiernsperger and J. Rapin, "Trace elements in glucometabolic disorders: an update," Diabetology \& Metabolic Syndrome, vol. 2, no. 1, article 70, 2010.

[24] K. Siddiqui, N. Bawazeer, and S. S. Joy, "Variation in macro and trace elements in progression of type 2 diabetes," Scientific World Journal, vol. 2014, Article ID 461591, 9 pages, 2014.

[25] E. S. Koh, S. J. Kim, H. E. Yoon et al., "Association of blood manganese level with diabetes and renal dysfunction: a cross-sectional study of the Korean general population," $B M C$ Endocrine Disorders, vol. 14, article 24, 2014.

[26] T. G. Kazi, H. I. Afridi, N. Kazi et al., "Copper, chromium, manganese, iron, nickel, and zinc levels in biological samples of diabetes mellitus patients," Biological Trace Element Research, vol. 122, no. 1, pp. 1-18, 2008.
[27] G. Nicoloff, K. Mutaftchiev, D. Strashimirov, and C. Petrova, "Serum manganese in children with diabetes mellitus type 1, Diabetologia Croatica, vol. 33, no. 2, pp. 47-51, 2004.

[28] A. S. Mueller and J. Pallauf, "Compendium of the antidiabetic effects of supranutritional selenate doses. In vivo and in vitro investigations with type II diabetic $\mathrm{db} / \mathrm{db}$ mice," Journal of Nutritional Biochemistry, vol. 17, no. 8, pp. 548-560, 2006.

[29] H. Steinbrenner, B. Speckmann, A. Pinto, and H. Sies, "High selenium intake and increased diabetes risk: experimental evidence for interplay between selenium and carbohydrate metabolism," Journal of Clinical Biochemistry and Nutrition, vol. 48, no. 1, pp. 40-45, 2011.

[30] A. Velayutharaj, R. Saraswathi, R. Shivakumar et al., "Association of serum magnesium with glycemic control and insulin resistance in patients with type 2 diabetes mellitus," International Journal of Current Research and Review, vol. 8, no. 13, pp. 17-23, 2016.

[31] D. P. Chaudhary, R. Sharma, and D. D. Bansal, "Implications of magnesium deficiency in type 2 diabetes: a review," Biological Trace Element Research, vol. 134, no. 2, pp. 119-129, 2010.

[32] A. Viktorínová, E. Tošerová, M. Križko, and Z. Ďuračková, "Altered metabolism of copper, zinc, and magnesium is associated with increased levels of glycated hemoglobin in patients with diabetes mellitus," Metabolism-Clinical and Experimental, vol. 58, no. 10, pp. 1477-1482, 2009.

[33] S. Swaminathan, V. A. Fonseca, M. G. Alam, and S. V. Shah, "The role of iron in diabetes and its complications," Diabetes Care, vol. 30, no. 7, pp. 1926-1933, 2007.

[34] H. Vasudevan and J. H. McNeill, "Chronic cobalt treatment decreases hyperglycemia in streptozotocin-diabetic rats," BioMetals, vol. 20, no. 2, pp. 129-134, 2007.

[35] S. D. Mussie, P. G. Kareru, J. M. Keriko et al., "Evaluation of the anti-diabetic potential of the methanol extracts of aloe camperi, meriandra dianthera and a polyherb," Journal of Diabetes Mellitus, vol. 5, pp. 267-276, 2015.

[36] H. Vatansev, H. Ciftci, A. Ozkaya, B. Ozturk, N. Evliyaoglu, and A. Kiyici, "Chemical composition of Nigella sativa L. seeds used as a medical aromatic plant from East Anatolia Region, Turkey," Asian Journal of Chemistry, vol. 25, no. 10, pp. 5490-5492, 2013.

[37] B. Shomar, "Major and trace elements in Nigella sativa provide a potential mechanism for its healing effects," Journal of Medicinal Plants Research, vol. 6, no. 34, pp. 4836-4843, 2012.

[38] P. Rathee, A. Hooda, S. Sushila et al., "Estimation herb/spice/ vegetables trace elements: north-west regional states of haryana (India)," Asian Journal of Pharmaceutical Technology and Innovation, vol. 3, no. 10, pp. 15-20, 2015.

[39] J. M. H. Anal, "Trace and essential elements analysis in Cymbopogon citratus (DC.) stapf samples by graphite furnaceatomic absorption spectroscopy and its health concern," Journal of Toxicology, vol. 2014, Article ID 690758, 5 pages, 2014.

[40] A. Kabata-Pendias, Trace Elements in Soils and Plants, CRC Press, Boca Raton, Fla, USA, 2011.

[41] I. Khan, J. Ali, and H. Tullah, "Heavy metals determination in medicinal plant Withania somnifera growing in various areas of peshawar, NWFP, Pakistan," Journal of the Chemical Society of Pakistan, vol. 30, no. 1, pp. 69-74, 2008.

[42] World Health Organization (WHO), Quality Control Methods for Herbal Materials, Revised, WHO, Geneva, Switzerland, 2011.

[43] World Health Organization (WHO), Guidelines for Assessing Quality of Herbal Medicines with Reference to Contaminants and Residues, WHO, Geneva, Switzerland, 2007. 

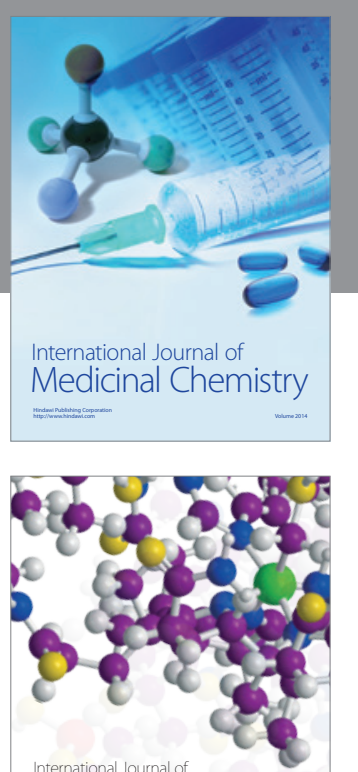

Carbohydrate Chemistry

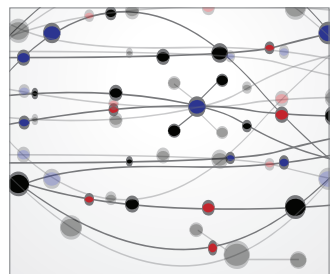

The Scientific World Journal
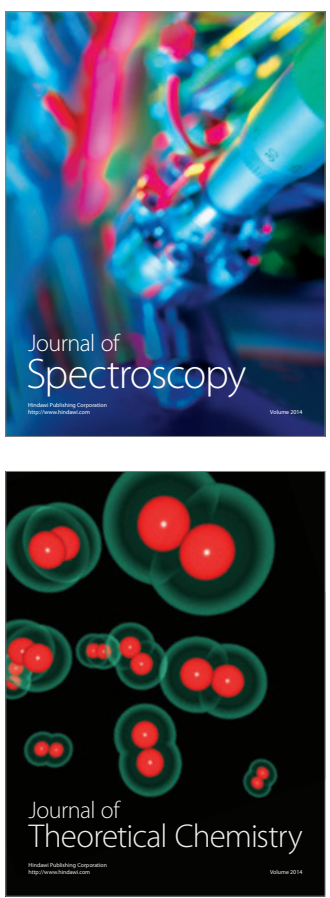
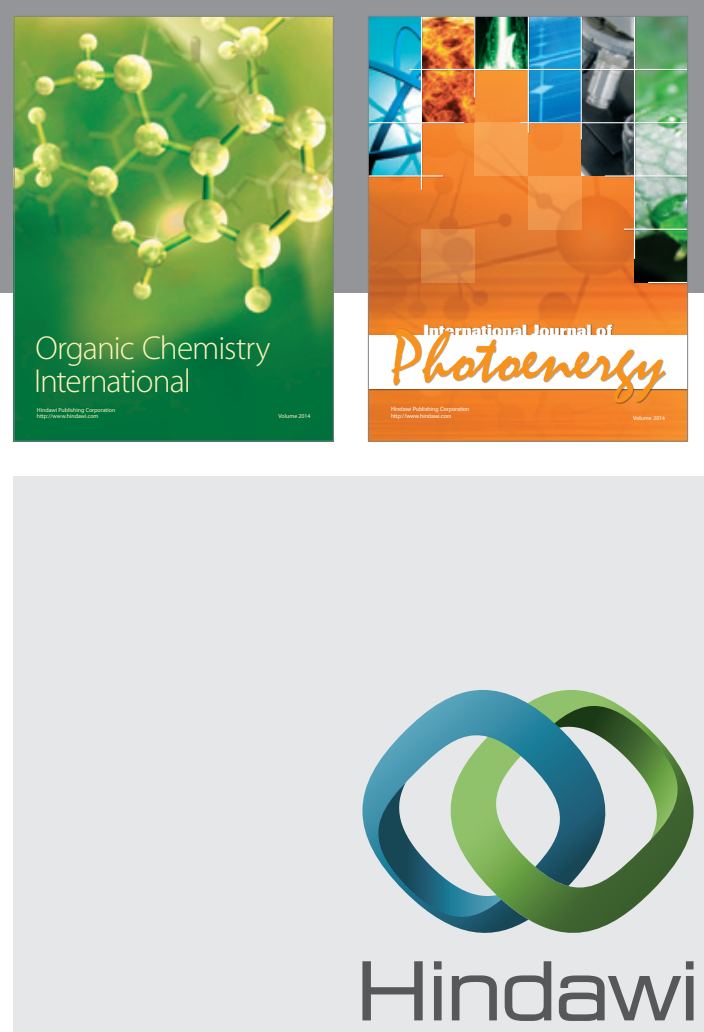

Submit your manuscripts at

http://www.hindawi.com

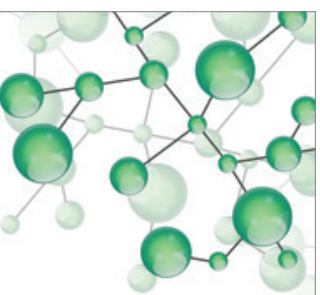

International Journal of

Inorganic Chemistry

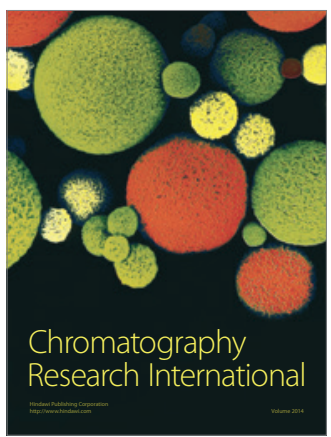

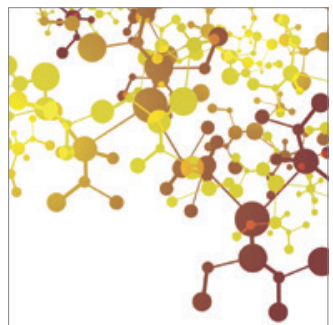

Applied Chemistry
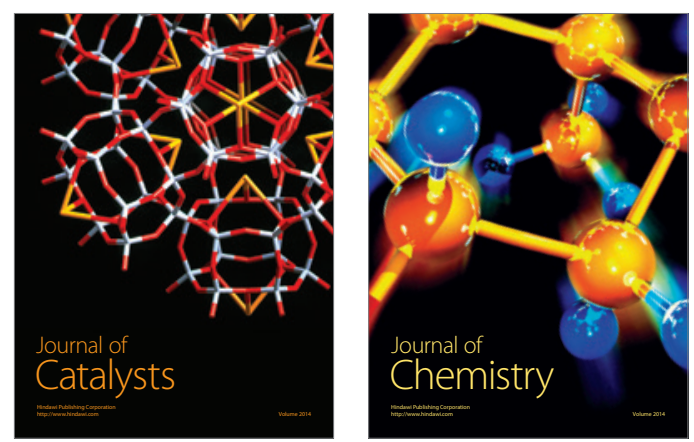
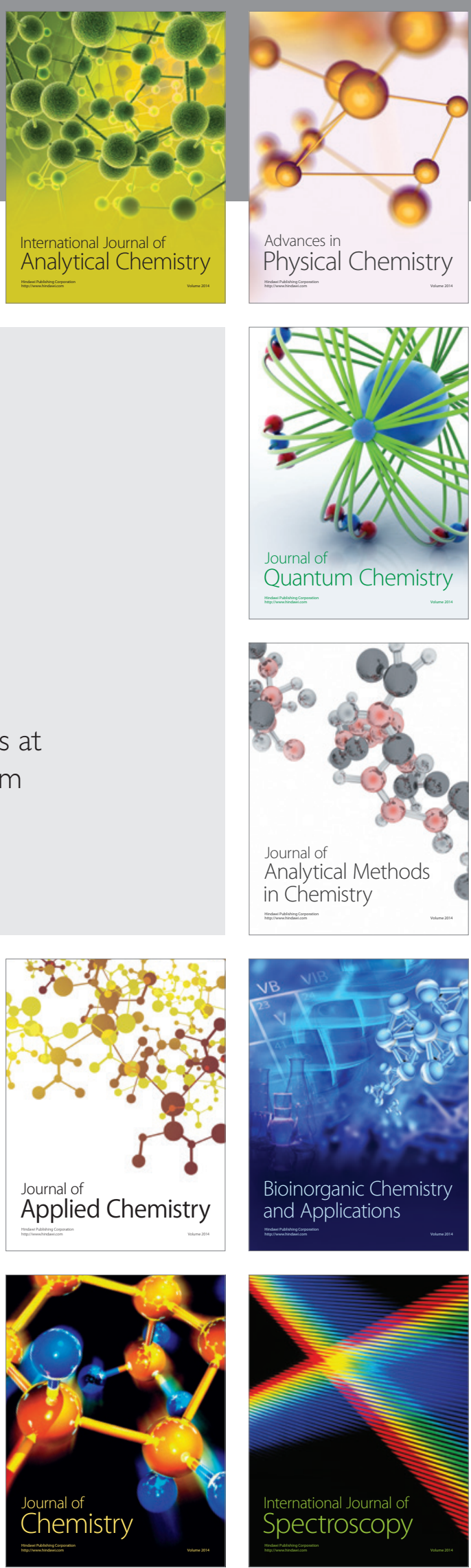